\section{DIGITAL COMMONS \\ @ UNIVERSITY OF SOUTH FLORIDA}

\section{ABO: Interactive Journal for Women in the Arts, 1640-1830}

Volume 2

Issue 1 Volume 2.1 (Spring 2012): Open Access

Article 6

2012

\title{
'The Only Beguiled Person': Accessing Fantomina in the Feminist Classroom
}

Kate Levin

Barnard College, klevin@barnard.edu

Follow this and additional works at: https://digitalcommons.usf.edu/abo

Part of the Dramatic Literature, Criticism and Theory Commons, Educational Methods Commons, Feminist, Gender, and Sexuality Studies Commons, and the Literature in English, British Isles Commons

\section{Recommended Citation}

Levin, Kate (2012) "'The Only Beguiled Person': Accessing Fantomina in the Feminist Classroom," ABO: Interactive Journal for Women in the Arts, 1640-1830: Vol.2: Iss.1, Article 6.

http://dx.doi.org/10.5038/2157-7129.2.1.5

Available at: https://digitalcommons.usf.edu/abo/vol2/iss1/6

This Pedagogy is brought to you for free and open access by Digital Commons @ University of South Florida. It has been accepted for inclusion in ABO: Interactive Journal for Women in the Arts, 1640-1830 by an authorized administrator of Digital Commons @ University of South Florida. For more information, please contact digitalcommons@usf.edu. 


\section{'The Only Beguiled Person': Accessing Fantomina in the Feminist Classroom}

\section{Keywords}

access, Eliza Haywood, Fantomina, feminism, seduction fiction

Creative Commons License

(c) (i) $\odot$

This work is licensed under a Creative Commons Attribution-No Derivative Works 3.0 License. 
"accessible”: "affording entrance; open”; [c]apable of being entered or reached. . .get-atable"; "open to the influence of"; "[a]ble to be (readily) understood or appreciated" (def $1-2 c)$.

A few years ago, I wrote an article comparing the experience of teaching Paradise Lost and Fantomina in a required first-year English class at Barnard College. ${ }^{2}$ In that article, I celebrated the feminist pleasures of teaching Haywood's work for its relative accessibility, which I claimed empowered my classes of all-female students to find their own voices. Since then, my students have seemed increasingly determined to prove me wrong. It's not that they don't find Fantomina accessible: they still find the story much less daunting than the complex thickets of Milton's epic. However, once inside Haywood's story, they have started to condemn her failures as a feminist. Thus, my earlier article now seems naïve and overly utopian, as well as somewhat under-informed.

Because of its representation of a sexually assertive and verbally expressive heroine, Haywood's story has been adopted into the canon of $18^{\text {th }}$-century feminist texts: a typical response is Catherine A. Craft's description of Fantomina as a "fantasy of female freedom" (830). And I've been teaching it from that perspective for over 10 years. In my syllabus, Fantomina follows directly after an intensive, intense (and sometimes very tense) two-week encounter with Paradise Lost. As such, my students and I have usually found Fantomina a relief and a pleasure both aesthetically and also ideologically; compared to the more compliant and subservient Eve, Fantomina seems like a liberated and almost contemporary heroine.

In my previous article, I described how Fantomina allowed my students to express themselves more freely after the structuralist rigors of Paradise Lost, how they seemed empowered by the title character, how they seemed to embrace the author's feminism-how a positive experience was had by all. Or so I thought. Lately though, I've noticed a change creeping into our discussions of Haywood's story that is starting to influence my own understanding of the story's feminism--or lack thereof-as well as sowing doubts about the feminism of my pedagogy. ${ }^{3} \mathrm{~A}$ number of students have started to resist my claims about this story's feminism. ${ }^{4}$ While they grant that Fantomina seems unusually active and assertive for an $18^{\text {th }}$-century heroine, they complain that she acts solely in relation to her male lover Beauplaisir and therefore should not be considered feminist. They also question my (and other feminist critics') reading of the ending, which views Fantomina's exile to a French convent as emancipating. ${ }^{5}$ By contrast, my students increasingly define this ending as Haywood's "selling out" of her heroine and her story's feminist possibilities - and increasingly defy my efforts to prove otherwise. In recent semesters several of them have even written eloquent essays about Fantomina as a failed feminist heroine and Fantomina as a failed feminist text. ${ }^{6}$

These seemingly irreconcilable differences between my feminist interpretive and pedagogical desires and my students' actual readings of Fantomina raise questions that serve as useful points of access for this inquiry: are $18^{\text {th }}$-century feminist texts so scarce (or even non-existent) that we sometimes pursue phantoms? Is that why I have been so excited to introduce my students to the seemingly feminist possibilities of Fantomina - and so surprised and even a little saddened when they resist my interpretation? Are my efforts to endorse (or enforce?) a feminist reading of 
Fantomina in the classroom paradoxically anti-feminist? What is a feminist classroom anyway? And why Fantomina?

My research for this article has led me in some strange and unexpected directions. I began and expected to remain in the safe and well-known domain of $18^{\text {th }}$-century studies, but along the way, I've ventured into the new and sometimes threatening territory of contemporary pedagogical theory (feminist and otherwise). However, although I may have strayed beyond the $18^{\text {th }}$ century in my quest for knowledge and search for answers, I have also found that the $18^{\text {th }}$ century itself offers some possible solutions_or at least the terms with which to begin to ask the right questions.

Thus my quest begins with Force or Fraud, Toni Bowers' recent book about seduction in $18^{\text {th }}$ century literature and culture. ${ }^{7}$ Bowers' book, which contains a chapter about Haywood, is above all an analysis of the phenomenon that she calls "collusive resistance" (4) She defines this as "an effort to maintain virtue in coercive situations by exercising submission and refusal simultaneously, a newly nuanced model for virtuous subjecthood that emerged in a time of severe constraint” (20). According to Bowers, this model, which originated in the political, cultural, and social upheavals of late $17^{\text {th }}$ - and early $18^{\text {th }}$-century England, became allegorized by the early writers of "seduction fiction":

the great Augustan seduction novelists—Behn, Manley, Haywood, and Richardsonwere fascinated by an endlessly repeated narrative situation in which a virtuous ingénue is pursued by a more-knowing, partially desirable seducer in a position of authority over her. . .it. . .was, for them, an urgent problem: how (and how far) to resist the demands of authority figures - figures both dangerous and desirable, to whom submission, while due, was problematic or even transgressive-without forfeiting Christian virtue. (23)

Bowers analyzes $18^{\text {th }}$-century gendered fictional archetypes, in particular the innocent but resistant female ingénue and the knowing male seducer, as allegorical representations of the struggles of actual $18^{\text {th }}$-century British subjects, most notably those tories who tried to remain loyal to their rulers under political conditions that often made it impossible to do so. ${ }^{8}$ I admire Bowers' cogent analyses of literary works and her insightful use of those analyses to revise $18^{\text {th }}$ century British political history - as well as her new framework for understanding the $18^{\text {th }}$ century novel. However, what I find most useful here are her original terms, which will serve as a valuable analogy for diagnosing my ongoing obsession and pedagogical struggles with Fantomina. In Bowers' terms, Fantomina might occupy the position of the "virtuous ingénue. . .pursued by a more-knowing. . . seducer in a position of authority over her." " But if we turn those terms into an analogy for my classroom situation, the analogy becomes Fantomina: Beauplaisir:: my students: me.

How shocking it seems to cast myself, even analogically, in the position of the (male) seducer! Although according to contemporary pedagogical theory, this is neither shocking nor particularly surprising. The idea of teaching as seduction dates back perhaps as far as Plato, but has certainly been theorized and written about profusely for at least 30 years. ${ }^{10}$ Joan De Jean defines this seductive potential in Biblical terms: 
[t]he archetype of such a relationship could well be the seduction of Eve by the serpent, who, like all the corrupt teachers who follow in its wake, gets the woman to do what it wants by offering her knowledge. Pedagogical corruption can thus be situated at the origin of original sin. (98)

While De Jean's formulation posits a "corrupt teacher," it almost goes without saying that by its very nature, all teaching (or at least all effective teaching) involves some kind of seduction of the student by the teacher. As Jane Gallop, the ur-theorist of teaching-as-seduction, describes it, "[a]t its most intense - and, I would argue, its most productive - the pedagogical relation between teacher and student is, in fact, a 'consensual amorous relation'” (Feminist 57). The student is by her very nature open ("accessible") to what the teacher has to offer - she is available and indeed expects to be "seduced," while the effective teacher also desires to seduce the student into his or her particular realm of knowledge, an experience that Mary Gordon describes as "[t]he familiar feeling of falling in love with a student” (222). Depending on its context, this model of teaching has either utopian or nightmarish possibilities. bell hooks's formulation represents the former: "[t]he academy is not paradise. But learning is a place where paradise can be created. The classroom, with all its limitations, remains a location of possibility” (207), while Gallop's actual experience represents the potential fallout of the latter. ${ }^{11}$ The negative risks originate in the natural imbalance of power present in every classroom: the teacher possesses something (knowledge, information, skills) that the student desperately wants or at least needs (in order to pass the class, graduate, get a good job, etc.). The teacher also controls the fate of each student at least in the short-term context of the classroom through the institutional power of the grade. ${ }^{12}$

When viewed as seduction, the phrase "feminist pedagogy" thus becomes almost oxymoronic. By its very nature, feminist pedagogy--and indeed most progressive pedagogy--is utopian. ${ }^{13}$ As part of its ideological mission, it aspires to create a non-coercive and loving relationship between equals, or at least a partnership of like-minded souls. In her article "What is Feminist Pedagogy?,” Carolyn M. Shrewsbury defines feminist pedagogy as

a vision of the classroom as a liberatory environment in which we, teacher-student and student-teacher, act as subjects, not objects. . .A classroom characterized as persons connected in a net of relationships with people who care about each other's learning as well as their own. ... The vision includes a participatory, democratic process in which at least some power is shared. (6-7)

In light of such definitions of feminist pedagogy, more than one feminist pedagogical theorist has viewed with suspicion or even rejected outright the idea of pedagogy-as-seduction: "an erotic pedagogy, I would argue more often than not involves serious sexual harassment of students, not only because of the unequal power relation but also because it creates a hostile work environment"” (Ebert 800). ${ }^{14}$ But some feminists do admit, albeit at times reluctantly, that seduction and pedagogy, along with their concurrent power inequities, are difficult if not impossible to separate. In describing her desire for a feminist pedagogical practice, Berenice Malka Fisher confesses that it is hard to avoid seduction (which she coyly labels "persuasion") in the classroom: "[t]he notion of a feminist teacher's accountability implies a definite restraint in how she employs her authority. Knowing that I am accountable to others prevents me from using my authority to try to simply persuade others to my point of view. Yet. . .Every aspect of 
teaching involves some element of persuasion” (93). While Christine Cusick and Laurie Mcmillan assert that "feminist pedagogy empowers students and provides opportunities for risktaking," they acknowledge that they "struggle to find an appropriate balance of power as [they] teach” (79). Kathryn Pauly Morgan sums up this problematic but inescapable paradox of feminist pedagogy:

if the feminist teacher actively assumes any of the forms of power available to her. . she eliminates the possibility of educational democracy in the feminist classroom; if she dispenses with these in the name of preserving democracy, she suffers personal alienation, fails to function as a role model, and abandons the politically significant role of woman authority. In short she stops functioning as a feminist teacher. (51)

Like all good teachers, don't we (feminists) want our students to agree with us--or at least to recognize that there might be some truth and value in the fruits of our hard-earned knowledge? And like all good progressive teachers, don't we also want our students to agree with us by choice, not by "force or fraud"? But how can we make that happen if not by seduction? Can even (or especially) we avoid the (patriarchal?) desire to penetrate students with our (phallic?) knowledge ${ }^{15}$ Do we also require their complete accessibility to our ideas and beliefs? ${ }^{16}$

Even if we do concede that seduction in the classroom is par for the course, we must acknowledge the even more painful truth that seduction, in the classroom or elsewhere, doesn't always go as planned. Sometimes the seducer risks rejection or at least resistance; as De Jean notes, every "class is, at least temporarily, out of the teacher's control” (116). This brings us back to my classroom struggles with Fantomina and indeed my desire for a more feminist pedagogical practice. À la Bowers, we might label my students' challenges to my feminist reading of Fantomina a kind of "collusive resistance": like those "besieged [ $18^{\text {th }}$-century] fictional women [who] labor to respond appropriately to the transgressive demands of men whom they are accustomed to obeying — and who, indeed, have a right to demand obedience” (Bowers 7), my students resist submission to my (feminist) authority even while often appearing to agree with me.

As hard as it is to admit, my students are right to resist my reading of Fantomina. Fisher describes her own limitations in the feminist classroom: "[n]o matter how valuable I think an exercise or assignment, [student] resistance serves as a warning to me that I need to reflect on my exercise of authority" (94). And my recent pedagogical struggles with Fantomina both remind me and help me to do that. There's a good reason (besides its current popularity ${ }^{17}$ ) that Bowers doesn't include this story in her Haywood chapter-for Fantomina doesn't quite fit her paradigm of virtuous female ingénue and knowing male seducer. In fact, it seems to exist at least in part to disrupt that paradigm. ${ }^{18}$ While Fantomina does start out (sexually) innocent, it is her "[g]ratification for an innocent curiosity"/her desire for (sexual) knowledge that propels the story's action (Haywood 227). And while Beauplaisir does initiate the story's first sexual encounter (an experience that numerous critics have characterized as rape ${ }^{19}$ ), Fantomina shows that she is a quick learner. After their initial encounter, she uses multiple disguises to trick Beauplaisir into believing that he is seducing her, all the while she is actually seducing him: "I have outwitted even the most Subtle of the deceiving Kind, and while he thinks to fool me is himself the only beguiled Person” (Haywood 239). As Tiffany Potter notes, Fantomina is in 
charge throughout most of the story: she "demonstrates her mastery not only of the linguistic codes of seduction and power in realms public and private, but also of the broader cultural signifiers of identity and power. She proves her skill. . in a competitive game with the man perceived to be the best” (179).

Throughout the story, Fantomina uses her hard-earned (sexual) knowledge to leap over boundaries and disrupt numerous binaries, among them male/female, subject/object, victor/victim, and of course seducer/seduced. ${ }^{20}$ Tassie Gwilliam comments how Fantomina serves a similar function for its readers: “[t]he reader of Fantomina. . .gets to have `female’ and 'male' pleasure, enjoying the spectacle of a series of animated sexual encounters powered by (her) constant love and (his) excitement at new conquests and by her skillful disguise and his blindness” (279). In this model, the reader's desire for a stable subject position is perpetually and perhaps even pleasurably disrupted: at any given point, are we Fantomina? Beauplaisir? Neither? Both? This disruption, as psychologically unnerving as it might feel, also has the potential to be powerfully productive, especially in the feminist classroom-for I hope by now that it is clear that Fantomina functions as an allegory as well as an analogy for my classroom experience. Although my students might initially (and almost certainly unconsciously) see me as occupying Beauplaisir's position of masculine authority in my role as The Teacher, Haywood's story works to undercut and expose that authority at every turn; for as Margaret Case Croskery points out, "[Beauplaisir is] objectified by his own desires in a way that [Fantomina] is not" (88). ${ }^{21}$

Not only does the story expose the limits of my classroom authority, it doesn't even allow me to occupy that position of authority consistently. Jo Keroes represents teaching as an act of masquerade: "[a]s much as they have license to self-display, teachers are entitled, even expected, to play a role, actually, to play a number of them and to enjoy the sensation of being watched, being the object of a collective gaze. . . The students' reward. . .is to partake of that performance. . ." (124). At least part of the teacher's power derives from the possibilities provided by masquerade, a position that supposedly makes the teacher's "true self" always inaccessible. But Fantomina (and Fantomina) uses masquerade in a way that holds a mirror up to and reverses the power differential of the classroom. As Juliette Merritt describes it, it is Fantomina, the erstwhile student, who masquerades in order to establish mastery over her alleged teacher and strip him of his power: "Beauplaisir is unaware. . .that it is he who has been seduced by an artful performance" (57). By doing so, Fantomina becomes the teacher: "her genius in metamorphosis, even though designed to appeal to male fantasy, is thrilling because it is a sign of her power to transcend her role as spectacle and achieve the position of the one who sees” (Merritt 60).

"Achieve the position of the one who sees": isn't that what we desire for our students? Yet how unnerving it is to give up (or at least share) some of our hard-earned power! For as we know, women have fought hard to be taken seriously in the front of the classroom as elsewhere. It's no accident that one of my students recently damned me with this faint praise on CULPA, the "unofficial” Barnard/Columbia teacher evaluation website: "Professor Levin is a great professor. At first. . .I thought she was not 'brilliant' enough to be an English professor at such a wellregarded institution, but my opinion quickly changed.” I suspect that more than one of my female colleagues will recognize the paradox that they embody as female authority figures. ${ }^{22}$ As Gallop notes, "[t]he positions that I thought of as real were me-female-student and my male teachers. . . [as a teacher] I felt I had switched genders. . .to experience the pedagogical positions 
as drag performance, role-playing. . .being the teacher' felt like a masquerade” (“Knot” 216-17). If female professors are always already performing a (gender) masquerade in the classroom, what do we risk by letting Fantomina unmask us? Will I, like Beauplaisir, have to storm out of the room when my students refuse to recognize my authority? Or will I also, like Beauplaisir, keep trying to "[renew] the Crime" (Haywood 248) in my desire for a different ending? ${ }^{23}$

What I have learned most of all as a student/teacher of Fantomina is that the "best way" to teach this story is to use it to ask questions rather than to demand answers, for Fantomina (like its heroine, who never unmasks) is most accessible not as it is "(readily) understood" or "get-atable" but rather as it is "open[-ended]." Even though or perhaps because Fantomina leaves Beauplaisir "more confused than ever he had known in his whole life" (Haywood 248), I agree with Croskery that "Fantomina makes it difficult. . .to identify this text's heroine as victim or victor" (90), that she "eludes characterization as a figure of rare female empowerment or ambiguous patriarchal collusion" (92). In the future, I plan to teach this story not by emphasizing Fantomina's feminist triumphs, but by highlighting the contradictions and complications that her story exposes both from its own time and from ours. ${ }^{24}$ Fantomina has also taught me along the way that encouraging my students to resist - or at least question--my authority is not a sign of feminist failure but of effective feminist teaching. ${ }^{25}$ After all, there have even been days when they have convinced me that their way of understanding Fantomina is the best way —or at least as legitimate as my own. For as Fantomina teaches us, the best seduction is always mutual: "if there be any true Felicity in an Amour such as theirs, both here enjoyed it to the full" (Haywood 244). ${ }^{26}$

Thanks to all of the "strong beautiful Barnard women" who have discussed, debated, and written about Fantomina so thoughtfully and passionately over the years; to my colleagues Elizabeth Auran, Collomia Charles, and Georgette Fleischer for their generous assistance with this project; and to Margaret Vandenburg, as always, for the opportunity. Thanks also to my many wonderfully seductive teachers. This project is dedicated to my mother, my first and best teacher. 
Notes:

1. Eliza Haywood 239.

2. See my article below. For a description of the Barnard First-Year English syllabi, see Margaret Vandenburg.

3. What do I mean by "feminism"? In my classroom we usually construct a mutually acceptable working definition along the lines of "the desire for equality between men and women," which occasionally morphs into more radical territory such as "the desire to undermine patriarchy." The question that then arises is whether Fantomina fits either definition, or both, or perhaps even neither. As Margaret J. M. Ezell warns in her insightful and still timely book Writing Women's Literary History, [the] belief in a uniform female response to life. . .enables us to identify with early women writers and to achieve a sense of a female literary family. Such a belief also results, at its crudest level, in a lamentable tendency to judge the "feminism" of earlier generations as it meets our standards. . .We worry whether our literary forebears were "good" feminists. (27)

One of the many valuable lessons I've learned from teaching Fantomina is that what I might like to think of as a universal one-size-fits-all definition of feminism is also a historical construct and perhaps even projection of my own $21^{\text {st }}$-century desires - and that this definition needs to be re-examined and refined in light of what actually takes place in Haywood's story. That may, however, be the subject of another essay altogether.

4. One of my students recently pointed out that Fantomina would fail the "Bechdel Test," which defines a work as more or less feminist according to the following criteria: "(1) it has to have at least two women in it, (2) who talk to each other, (3) about something besides a man” (Bechdel).

5. See for example Margaret Case Croskery: “in Haywood's works, banishment to convent or monastery was no guarantee of moral transformation, nor was it an effective stopgap to erotic pleasure. The story's ending suggests not a conclusion, but a sequel. . .Fantomina never formally chastises its heroine” (92).

6. In one of these essays, a student even revised the ending to have Fantomina kill her lover and move on to other men. She thus justified her version as more feminist than Haywood's:

The original Fantomina has an ending that does not do justice to a wondrously disturbing and seemingly pro-woman story. Haywood was writing in a time when women were, more often than not, seen as inferior to men. . .Although this might explain the reason for Fantomina's lackluster ending, that does not mean the story had to end this way. . .the new ending. . . allows the reader to come away with a message that does not point to the woman as the victim but rather characterizes her as the dominant, powerful, and intelligent force of the narrative. 
7. Here I must confess that while my previous article originated as a tribute and response to John Richetti, a pedagogical "father" who served as my dissertation advisor, this one has been inspired by a pedagogical "mother": it was Toni Bowers who first introduced me to $18^{\text {th }}$-century women writers, including Haywood, and who also served on my dissertation committee.

8. Bowers calls such individuals "tories” (or oppositely, “whigs”) in order to distinguish them from the more official political party designations of "Tory" and "Whig": "I mean precisely to distinguish partisanship_-a conscious, programmatic commitment to getting or keeping power in the hands of a certain recognized group (the Tories, the Whigs) in order to direct public policy in certain ways - from ideological sensibility-a more amorphous matter of values, attitudes, and default assumptions” (5).

9. Bowers doesn't discuss Fantomina in her book for a number of reasons that should become clear shortly.

10. For example, see the articles in Regina Barreca and in The Pedagogical Imperative along with all works below by Jane Gallop. For a discussion of pedagogical seduction in Plato, see Jo Keroes (2) and Chrissie Tan.

11. Like De Jean, Gallop acknowledges the potential for corruption (inherent in the always present possibility/threat of actual physical seduction) in the teacher-student relationship, a possibility conceded by the very title of her book, Feminist Accused of Sexual Harassment.

12. Ira Shor calls this "the unequal power zone of the classroom. I am, after all, the teacher, the one assigned by the institution to do education to them, the only person in the room with the power to give grades" (51).

13. For insightful discussions of progressive pedagogy, see books by Michael Bérubé and by Shor. Feminist pedagogy seems to share most (if not all) of its methods with other forms of progressive pedagogy and differs mostly (if not always) in terms of content: its focus on women's experience and/or gender definitions.

14. As a feminist Marxist, Teresa L. Ebert criticizes a feminist erotics of pedagogy for its denial of the unequal power relations of the classroom:

the erotic relation is seen as an isolated, ahistorical, noninstitutional "free” space of "free" individual desire that undoes hierarchies through the reversible, negotiable relation of "seducer" and "seduced.” But the professor-student relation is not a "free" space outside institutions and domination. The negotiation of power in an "unequal relationship" is always a negotiation in which the one with (institutional) power sets the terms. (803)

15. The metaphor is Gallop’s, drawn from her analysis of Sade ("The Immoral Teachers" 118). 
16. As Chris Amirault describes this situation, ”far from being a good teacher, I was practicing the worst kind of pedagogy, one thoroughly caught up with my own narcissistic reproductive desire, striving to produce little copies of myself in my students" (70).

17. Laura Runge points out that Fantomina currently appears in at least four literary anthologies and asks, “do we really need that many Fantominas?” (149). Bowers and Stephanie Harzewski also observe that "during the 1990s, Fantomina received a proliferation of feminist readings and. . .indispensably fueled the Haywood Renaissance" (505 n. 13). Because of this "proliferation," I will assume that my readers are already familiar with the details of the story's plot.

18. In fact, I think that one of the reasons for Fantomina's current popularity is its interpretive ambiguity (which is bound to appeal to a post-modern audience). For example, one way that it evades or at least disrupts our assumptions about the story's feminism is the ambiguity of its definition of seduction: unlike the examples in Bowers' book, we are never quite sure from one moment to the next who is seducing whom.

19. See for example Ros Ballaster 188.

20. Croskery observes that "the heroine's disguise continues to confuse the roles of seducer and seduced” (84).

21. More than one student has revealed her own identification with Fantomina, as in this opening of a recent essay about Fantomina: "I would like to say that I am a 'Young Lady of distinguished Birth, Beauty, Wit.”'

22. I believe that the contradictory nature of my student's comment reflects at least in part my decision to make myself relatively accessible to my students. Madeleine Kahn remarks that this problem may be endemic to the role of a female professor at a women's college: "my professional distance was under siege from the moment I walked into a classroom at Mills. I was subjected to intense-even passionate-scrutiny, and every boundary I tried to establish was immediately tested” (11).

23. As Croskery mentions, at the end of the story, "Beauplaisir is once again enamored" (92).

24. Bowers notes that "by coming to understand the history of certain modern assumptions about the reciprocal power of men and women in intimate relation, we can. . .use that perception to think critically about the present” (25). My experience suggests that this "history" can be used to analyze all power dynamics, not just those between "men and women in intimate relation.”

25. In keeping with the tradition of the best progressive feminist pedagogy, I hope that I can encourage my students to become more whig than tory by making their resistance to my authority outright rather than collusive. 
26. If we follow the allegory to its endpoint, we could say that Fantomina, impregnated with Beauplaisir's "knowledge," gives birth to a baby girl who will adhere to and perhaps advance her mother's story — or perhaps the two of them will go off together to found a community of female scholar-courtesans in France. 


\section{WORKS CITED}

“Accessible.” The Oxford English Dictionary. 2nd ed. 1989. Print.

Amirault, Chris. "The Good Teacher, the Good Student: Identifications of a Student Teacher.” Pedagogy: The Question of Impersonation. Ed. Jane Gallop. Bloomington: Indiana UP, 1995. 64-78. Print.

Ballaster, Ros. Seductive Forms: Women's Amatory Fiction from 1684 to 1740. Oxford: Clarendon, 1992. Print.

Barreca, Regina, and Deborah Denenholz Morse, eds. The Erotics of Instruction. Hanover, NH: UP of New England, 1997. Print.

Bechdel Test Movie List. N.p., n.d. Web. 28 May 2011.

Bérubé, Michael. What's Liberal about the Liberal Arts?: Classroom Politics and "Bias" in Higher Education. New York: Norton, 2006. Print.

Bowers, Toni. Force or Fraud: British Seduction Stories and the Problem of Resistance 16601760. Oxford: Oxford UP, 2011. Print.

Bowers, Toni, and Stephanie Harzewski. "An Unfinished Renaissance: New Editions of Eliza Haywood.” Review Essay. The Age of Johnson 13. Ed. Paul J. Korshin and Jack Lynch. New York: AMS, 2002. 473-507. Print.

Craft, Catherine A. "Reworking Male Models: Aphra Behn’s Fair Vow-Breaker, Eliza Haywood's Fantomina, and Charlotte Lennox's Female Quixote.” Modern Language Review 86.4 (1991): 821-38. Print. http://dx.doi.org/10.2307/3732539

Croskery, Margaret Case. “The Politics of Passion in Eliza Haywood's Fantomina.” The Passionate Fictions of Eliza Haywood: Essays on Her Life and Work. Ed. Kirsten T. Saxton and Rebecca P. Bocchicchio. Lexington: UP of Kentucky, 2000. 69-94. Print.

CULPA.info. N.p. 2011. Web. 19 Dec. 2011.

Cusick, Christine, and Laurie Mcmillan. "Feminist Faculty Negotiate the Land of Both/And." Studies in the Humanities 36.2 (2009): 77-86. ProQuest. Web. 29 May 2011.

De Jean, Joan. "La Nouvelle Hélöise, or the Case for Pedagogical Deviation.” The Pedagogical Imperative 98-116.

Ebert, Teresa L. "For a Red Pedagogy: Feminism, Desire, and Need." College English 58.7 (1996): 795-819. ProQuest. Web. 18 May 2011. http://dx.doi.org/10.2307/378415 
Ezell, Margaret J. M. Writing Women’s Literary History. Baltimore: Johns Hopkins UP, 1993. Print.

Fisher, Berenice Malka. No Angel in the Classroom: Teaching Through Feminist Discourse. Lanham, MD: Rowman \& Littlefield, 2001. Print.

Gallop, Jane. Feminist Accused of Sexual Harassment. Durham, NC: Duke UP, 1997. Print.

---. “The Immoral Teachers.” The Pedagogical Imperative 117-28.

---. "Knot a Love Story.” Yale Journal of Criticism 5.3 (1992): 209-18. ProQuest. Web. 18 May 2011.

Gordon, Mary. "Teaching Elders: A Journal.” Women/Writing/Teaching. Ed. Jan Zlotnik Schmidt. Albany: State U of New York P, 1998. 213-29. Print.

Gwilliam, Tassie. "Disguise, Fantasy, and Misrecognition in The Belle's Stratagem and Fantomina." Teaching British Women Playwrights of the Restoration and Eighteenth Century. Ed. Bonnie Nelson and Catherine Burroughs. New York: MLA, 2010. 275-84. Print.

Haywood, Eliza. Fantomina: Or, Love in a Maze. Popular Fiction by Women 1660-1730: An Anthology. Ed. Paula R. Backscheider and John J. Richetti. Oxford: Clarendon, 1996. 226-48. Print.

hooks, bell. Teaching to Transgress: Education as the Practice of Freedom. New York: Routledge, 1994. Print.

Kahn, Madeleine. “Why Are We Reading Ovid's Handbook on Rape?”: Teaching and Learning at a Women's College. Boulder: Paradigm, 2005. Print.

Keroes, Jo. Tales Out of School: Gender, Longing, and the Teacher in Fiction and Film. Carbondale, IL: Southern Illinois UP, 1999. Print.

Levin, Kate. “'Imagining a World of Satisfaction’: The Challenges and Pleasures of Teaching Eliza Haywood's Fantomina.” The Eighteenth-Century Novel, Vols. 6-7: Essays in Honor of John Richetti. Ed. Albert J. Rivero and George Justice. New York: AMS, 2009. 497-508. Print.

Merritt, Juliette. Beyond Spectacle: Eliza Haywood's Female Spectators. Toronto: U of Toronto P, 2004. Print.

Morgan, Kathryn Pauly. "The Perils and Paradoxes of Feminist Pedagogy.” Resources for Feminist Research/Documentation sur la Recherche Féministe 16.3 (1987): 49-52. ProQuest. Web. 29 May 2011. 
The Pedagogical Imperative: Teaching as a Literary Genre. Spec. issue of Yale French Studies 63 (1982). JSTOR. Web. 17 May 2011.

Potter, Tiffany. "The Language of Feminised Sexuality: Gendered Voice in Eliza Haywood's Love in Excess and Fantomina.” Women's Writing 10.1 (2003): 169-86. Taylor \& Francis Online. Web. 7 Aug. 2011. http://dx.doi.org/10.1080/09699080300200182

Runge, Laura. “Teaching Eighteenth-Century Women Writers.” Literature Compass 7.3 (2010): 145-59. Blackwell Publishing. Web. 1 Mar. 2011. http://dx.doi.org/10.1111/j.17414113.2009.00692.x

Shrewsbury, Carolyn M. “What is Feminist Pedagogy?” Women’s Studies Quarterly 15.3/4 (1987): 6-14. JSTOR. Web. 4 Mar. 2011.

Shor, Ira. When Students Have Power: Negotiating Authority in a Critical Pedagogy. Chicago: U of Chicago P, 1996. Print.

Tan, Chrissie. "Seduction in the Eyes of the University." Parallax 12.3 (2006): 78-84. Taylor and Francis Online. Web. 3 Mar. 2011. http://dx.doi.org/10.1080/13534640600771969

Vandenburg, Margaret. "Reinventing Literary History at Barnard College.” Integrating Literature and Writing Instruction: First-Year English, Humanities Core Courses, Seminars. Ed. Judith H. Anderson and Christine R. Farris. New York: MLA, 2007. 6380. Print. 